\title{
Equilibrium
}

Quarterly Journal of Economics and Economic Policy

VOLUME 8 ISSUE 3, 2013

ISSN 1689-765X, (Online) ISSN 2353-3293

http://www.equilibrium.umk.pl/

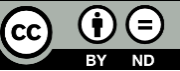

Bielawska M., Calderón Vázquez F.J. (2013), Growth Versus No-growth: The Contractive Evolution of $R \& D$ Policies in Spain and Andalusia, "Equilibrium. Quarterly Journal of Economics and Economic Policy”, Volume 8, Issue 3, pp. 49-61, DOI: http://dx.doi.org/10.12775/EQUIL.2013.019

\author{
Magdalena Bielawska \\ Francisco J. Calderón Vázquez* \\ University of Malaga, Spain
}

\section{Growth Versus No-growth: The Contractive Evolution of R\&D Policies in Spain and Andalusia}

JEL Classification: 030,038

Keywords: knowledge-based economy, research and development (R\&D), innovation policy, growth and development, innovation

Abstract: The current economic crisis and the building-based economy collapse make the innovation approach and the change to knowledge-based economy fundamental to trace the future growth and development. This paper revises the $R \& D$ policy in Spain and Andalusia in the last 10 years with the evolution of the main indicators during the period 2001-2011.

\section{Introduction}

The importance of $\mathrm{R} \& \mathrm{D}$ policies for growth and economic development are not underestimated and, moreover, they are crucial for peripheral countries. The current adverse economic situation could restrain the financing for these policies. Due to the European competiveness loss with respect to other industrialized and emerging countries, the Lisbon Strategy directed at converting Europe into a knowledge-based economy following a strategy where the

(C) Copyright Institute of Economic Research \& Polish Economic Society Branch in Torun Date of submission: March 1, 2013; date of acceptance: June 25, 2013

* Contact: magda.biel@uma.es, fjcalderon@uma.es, University of Malaga, Avda. Cervantes, 2 29071, Malaga, Spain 
development based on R\&D and innovation was an essential part. One of the planned steps was to reach the objective of 3\% GDP dedicated to these poli$\operatorname{cies}^{1}$, in order to balance the life conditions and welfare between the different regions within Europe.

As the building-based growth has finished and the labor costs competitiveness has become inefficient on the global market, there are some questions that have to be posed: which is the strategy for the future economic growth and development for the Mediterranean countries? Which is the one for Spain? Inside this strategy, what is the role of R\&D and innovation and how can it boost it? In order to answer these questions, first of all, we need to know what the current situation of Spain and Andalusia is and characterize it in these terms and in terms of its evolution.

The technological change has been a recurrent element in development and growth theories since Adam Smith based its origin in work division, but is J.A. Schumpeter who will link the economic development and business competiveness with technological innovation, considering the entrepreneur as the engine of the innovation (Schumpeter 1933; 1967; 1968). Many subsequent studies will prove the positive relations between the economic growth and the technological development (Abramovitz 1956; Solow 1956) measured by elements as number of scientists, $R \& D$ expenditures, patents granted or scientific publications. These ones are essential to create competitive advantages (Solow 1957; Salter 1960; Denison 1962). In the eighties, some authors put valued the public policies for its infrastructure support for enterprises, as well as the R\&D and human capital (Romer 1986; 1990; Lucas 1988). Moreover, some international institutions affirm the link between knowledge accumulation and the general productivity increase (OECD 1998; OECD \& EC 2005). The correlation between R\&D and productivity was finally proved for the OECD countries by Coe and Helpman (1993). The specialization in R\&D activities is a main part of the technical progress of our times (Freeman et al. 1982; Freeman, Soete 1997).

The objective of this paper is to review the ten-year tendency of these policies in Spain and Andalusia, and its implications for the future growth and development. The public policies guide and put the framework to stir up innovation that transforms ideas into products and services. The case of Spain and Andalusia seems to be important due to the new scenario, as facing less European funds for the next period could affect the public policies and reduce the innovation capacity reached so far. Andalusia forms part of this study for its economic and demographic importance in the complex of Spain and for being one of the regions classified as Objective 1 (due to its

\footnotetext{
${ }^{1}$ Only reached by Sweden, Finland and Denmark
} 
GDP lower than the European Union average) in terms of financing from European funds.

In this sense, according to the European Regional Innovation Scoreboard $(\mathrm{RIS})^{2}$, Spain is a moderate innovator, but there is a large variance in innovation performance with 8 modest innovators, 6 moderate innovators and 5 innovation followers regions (see: Hollanders et al. 2012, p.15). In this report Spain was considered as Moderate Innovator in years of 2007, 2009 and 2011. However, in the Spanish context, we can find regions with higher innovator levels, such as Catalonia and Basque Country (Innovation Followers) and other with lower levels, such as Andalusia or Castilla la Mancha (Modest Innovator). In addition, the Andalusia regional analysis masks the inner differences, as there are quite distance between towns' innovation capacity levels inside the region (Gonzalez, Romero 2010, p. 241).

\section{Methods and Content of the Article}

In this paper we will arrange a study case of the contractive situation of the $\mathrm{R} \& \mathrm{D}$ sector in the context of the economic crisis in Spain and its regions, particularly the situation of a peripheral region like Andalusia in the framework of the European Union. Basically, we will review the evolution of the main indicators of R\&D and innovation in Spain and Andalusia. The paper is structured as follows. On the one hand, the second paragraph describes the sector characterization starting by R\&D expenditure and its structure. On the other hand, in the same paragraph we analyze the human resources devoted to these activities, the evolution of medium-high and high technology companies, including its employment. At the end of this section we review research groups funding.

In the third paragraph, we close with some conclusions about the importance of this sector in a peripheral region such as Andalusia, remarking the contradictions between the contractive public sector funding and its future growth potential.

\footnotetext{
${ }^{2}$ RIS is a comparative study of 190 European regions that classifies them in four different groups due to its innovation performance: Innovation Leader, Follower, Moderate and Modest Innovator.
} 


\section{Sector Characterization}

\section{Research and Development Expenditure}

Spain's objective of $3 \%$ of GDP on R\&D expenditure is far distant from the Lisbon target, as we can see in Figure 1. It reached the highest point of $1,39 \%$ in 2009 , maintained stable in 2010 , and finally declined in 2011 . The forecast for 2012 is even worse.

In 2011 , the total expenditure was 14.184 million $€$ that supposed $1,33 \%$ of GDP meanwhile the UE-27 stayed at $2,03 \%{ }^{3}$. At national level, the total expenditure accounted 303 Euros per capita in 2011, quite remote to $600 €$ of the Germany, France or UK. Although the GDP in 2011 had grown up with respect to the 2010 , the $R \& D$ expenditure was reduced $2,8 \%$ comparing to 2010. The 2009 was a turning point year in the growth tendency, and became the beginning of a decline till 2011, for both public and private expenditure. The mayor part of decline was observed in the public expenditure of 5,7\%, while private companies reduced it only by $1,5 \%$. However, the public and private expenditure $(53 \%)$ are almost similar, slightly exceeded by the private sector, but this balance is far from the Andalusia expenditure structure, where the private expenses are quite lower than the public ones.

Figure 1. Structure of R\&D expenditure in Spain in 2001-1011 (share of expenditures in $\%$ of GDP)

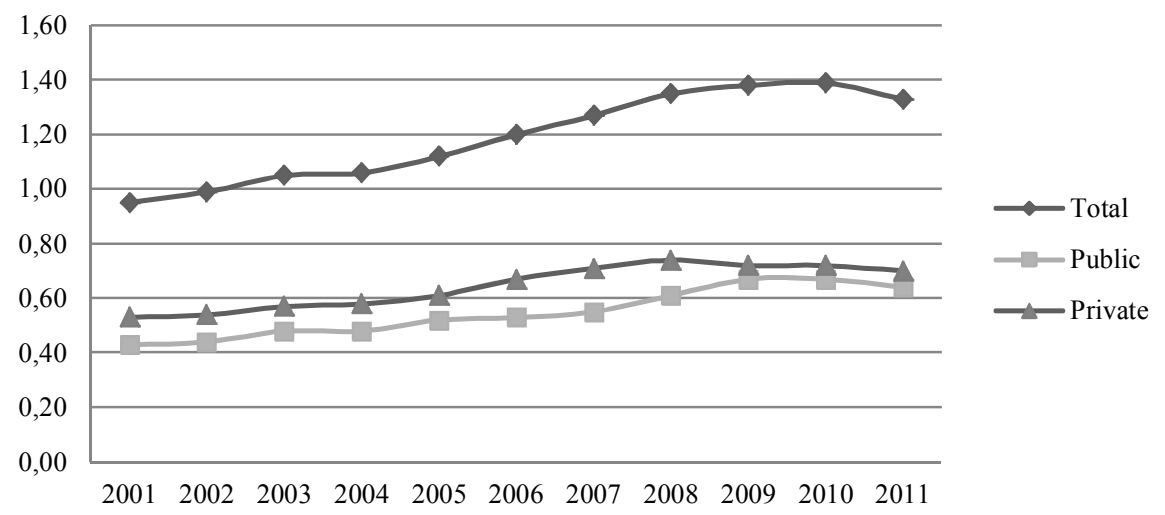

Source: own elaboration based on data from Spanish National Stadistics Institute (2013), www.ine.es.

\footnotetext{
${ }^{3}$ Eurostat database
} 
Andalusia, region with $17,8 \%$ the population of the whole Spain, contributes $13,6 \%$ to the Spanish GDP, but it represents only $11,6 \%$ of the total national $\mathrm{R} \& \mathrm{D}$ expenditure, making comparison to Madrid and Catalonia which are almost half of the national expenditure. Even occupying the fifth position in 2011 amongst Spanish regions in expenditure, Andalusia is still below the 3\% target newly set for 2020 by the European Strategy. The Andalusia effort of $1,13 \%$ GDP with 1.648 million $€$ expenditure is lower than the Spanish national average, Portugal, Ireland and Italy, but higher than Greece.

There is a positive correlation between the regional GDP per capita and regional R\&D expenditure per capita (EOI 2010, p. 41). In this sense, Andalusia, as the convergence region, had the regional expenditure per capita in 2011 at $197 €$, while the national average was 303, far behind from the Spanish leader, the Basque Country, with its $639 €$ per habitant.

Andalusia's expenditure effort (Figure 2) seemed to be steadily growing in this period, reaching $1,2 \%$ of GDP in 2010, shrinking the widespread distance to the national level ${ }^{4}$. However, it declined in 2011 to $1,13 \%$, as did the national one. Although the expenditure effort is appreciated, when comparing to national yearly growth rate, the Andalusia $R \& D$ expenditure is half of the one of Catalonia or Madrid in absolute terms. This low performance is one of the reasons why the European Regional Innovation Scoreboard (RIS) ${ }^{5}$ classified Andalusia in the last group. This level is common for the southern and eastern European countries as the RIS had highlighted: Most of the moderate innovators are found in Czech Republic, Italy, Portugal and Spain, and most of the modest innovators in Bulgaria, Hungary, Italy, Poland, Portugal, Romania, Slovakia and Spain (p. 13).

Although Spain was situated in Moderate Innovation level in 2007, 2009 and 2011 Andalusia worsens its position with respect to 2009 as Moderate to down in 2011 to Modest one. The RIS evaluates three categories (Enablers, Firm Activities and Outputs), and Andalusia shows better performance indicators for Enablers, such as the population with tertiary education and public $\mathrm{R} \& \mathrm{D}$ expenditures. On the other hand, the weaknesses are evidenced in series of factors belonging to the Firm Activities performance (private R\&D, SMEs innovating in-house, innovative SMEs collaborating) and Outputs (technological and non-technological innovators and employment in medium high and high-tech manufacturing and knowledge intensive services companies).

\footnotetext{
${ }^{4}$ The national expenditure grew steadily from $0,95 \%$ in 2001 to $1,33 \%$ in 2011 .

${ }^{5}$ RIS provides statistical facts on regions' innovation performance for 190 regions from 21 EU Member States, Croatia, Norway and Switzerland and distinguished in 2011: 113 innovation leaders, 165 innovation followers, 121 moderate innovators and 171 modest innovators
} 
Figure 2. R\&D expenditure in Spain and Andalusia from 2001 to 2011 (share of expenditures in \% of GDP)

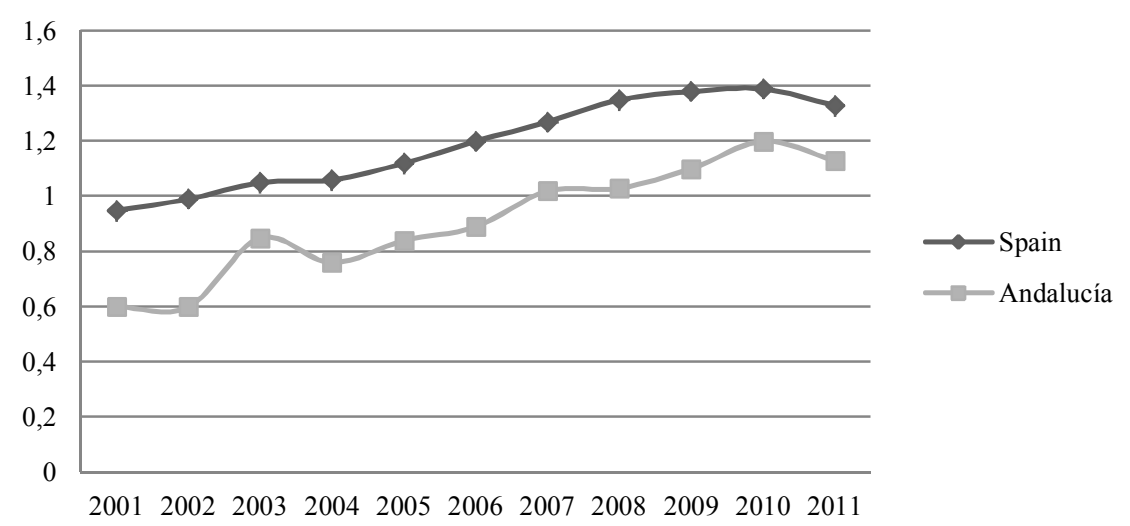

Source: own elaboration based on data from Spanish National Statistics Institute (2013), www.ine.es.

The Spanish expenditure tendency is more stable comparing to the Andalusian one, which is more irregular with peak in 2003. Meanwhile at the national expenditure structure, the private sector prevails (approximated 55\% highlighting Basque Country and its $80,9 \%$ private expenditure) Andalusia public expenditure is much more important (64\%).

Figure 3. R\&D expenditure structure in Andalusia 2001-2011 (thousands of millons of Euros)

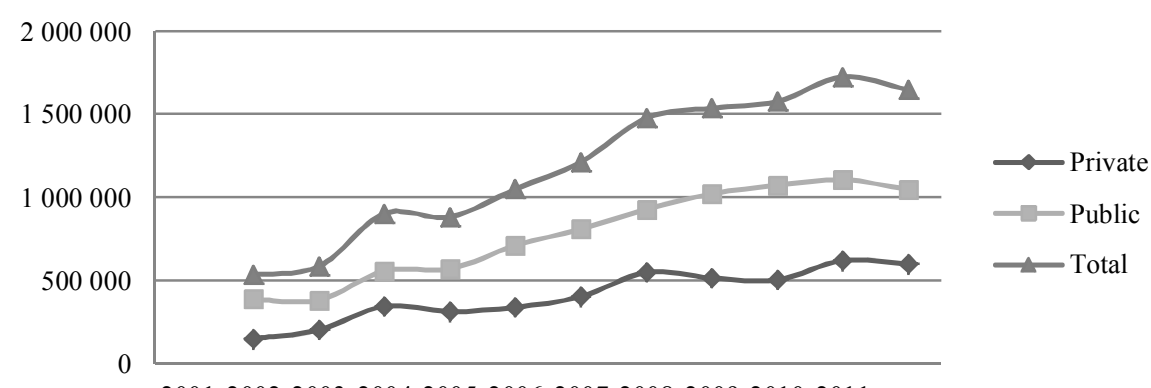

20012002200320042005200620072008200920102011

Source: own elaboration based on data from Estadística sobre actividades de $I+D$. Resultados para Andalucía 2010 from Institute of Statistics and Cartography of Andalusia (Instituto de Estadística y Cartografia de Andalusia) based on Spanish National Statistics Institute database (INE). 
The Figure 3 presents the evolution of Andalusia structure of the R\&D expenditure by sectors. Although the private expenditure has grown up more than other regions, reaching $36 \%$, it is still lower than the national average (53\%). Regardless of the regional GDP falling in 2009, there was an increase in financial efforts from 2010 with the rise of R\&D expenditure mainly due to the public participation - universities execute the main part of the public R\&D funds - till the downfall in 2011 reducing 5,1\% (public) and 3,4\% (private) reaching a loss of 78,295 million $€$ compared to the previous year.

\section{Human Resources}

Approximately 215.079 employees were dedicated to R\&D activities in 2011 in Spain, but the number suffered a decline of 3,1\% in respect to the previous year. The loss of researchers was quite similar, 3,3\%, and remained at 130.235. During this period, the continuous growth trend allowed the increase from 6,9 in 2001 to 11,9 in 2011 R\&D employees per thousand habitants (from 125.750 in 2001 to 215.079 in 2011). The increase in the number of researchers was quite similar, moving from 80.081 to 130.235 , and the proportion grew from 4,4 to 7,2 per thousand. The main part, almost $58 \%$ of total employees and $65 \%$ of researchers, were employed in the public sector. In the 2011, the downfall was more stressed in the public sector with $4,4 \%$, while the private one only decreased by $1,2 \%$ comparing to 2010 .

Figure 4. Evolution of R\&D employees and researchers in Spain 2001-2011 (full time equivalent)

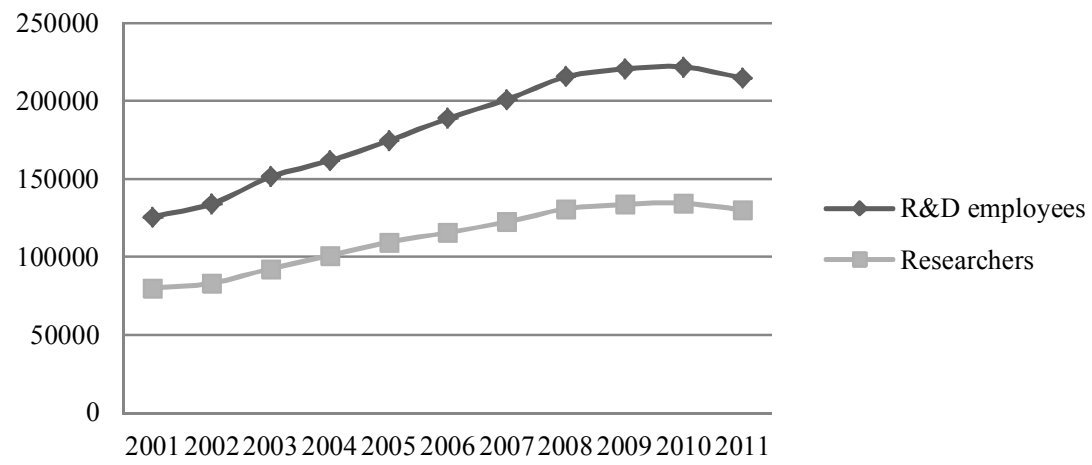

Source: own elaboration based on data from Spanish National Stadistics Institute (2013), www.ine.es. 
In 2011, Andalusia had 25.434 employees (included 14.610 researchers) that comprised $11,8 \%$ of the whole national number - the third region following autonomous community of Madrid (23,8\%) and Catalonia (20,7\%). However, these figures still remained below the national level of 11,9 , with 9,2 employees and 5,3 researchers (7,2) per thousand occupied. Almost 71\% of employees work for the public sector, and this one presented the decline of $2,04 \%$ respect the previous year (Figure 5)

Figure 5. The R\&D employees by sectors in Andalusia 2001-2011

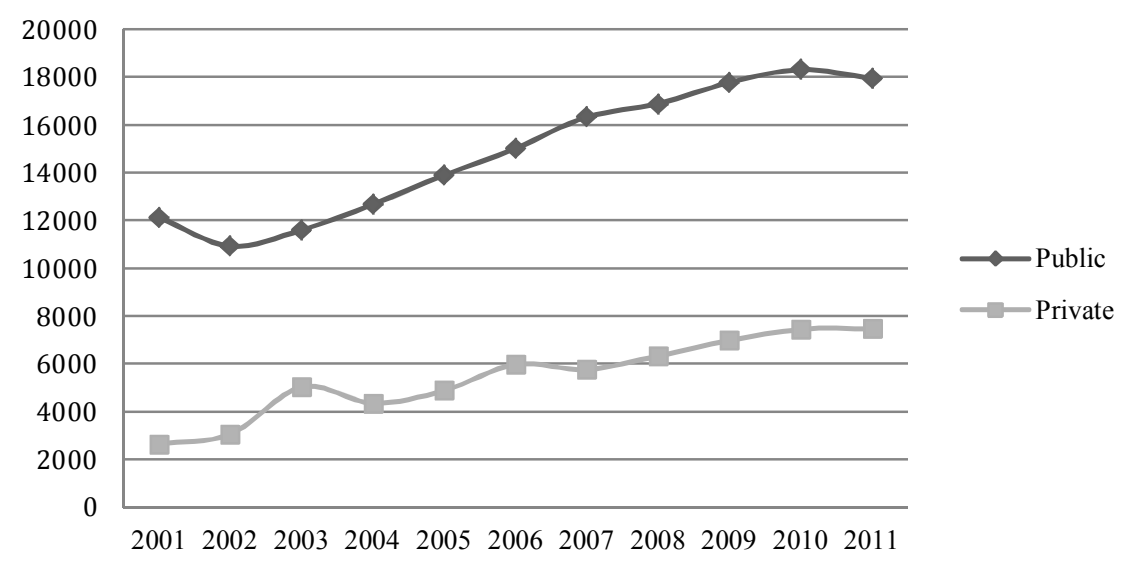

Source: own elaboration based on data from ,Indicadores del Sistema Andaluz de Ciencia y Tecnologia 2010" based on SICA Inventary (2010, p. 18) and Estadística sobre actividades de I+D. Resultados para Andalucía 2010 from Institute of Statistics and Cartography of Andalusia.

\section{Medium High and High Technology Companies}

At national level, the number of companies that were medium-high and high technology manufacturing was growing from 2002 till 2007 to double its number (from 1.570 to 3.170), and then started declining to show even fewer companies (2.354) in 2011 than in 2003 (2.389). 
Table 1. High and medium high technology companies and employment in Spain and Andalusia 2002-2011

\begin{tabular}{|c|c|c|c|c|c|c|c|c|}
\hline \multirow{3}{*}{ Year } & \multicolumn{4}{|c|}{ Spain } & \multicolumn{4}{|c|}{ Andalusia } \\
\hline & \multicolumn{2}{|c|}{$\begin{array}{l}\text { Number of } \\
\text { companies }\end{array}$} & \multicolumn{2}{|c|}{ Employment numbers } & \multicolumn{2}{|c|}{$\begin{array}{l}\text { Number of } \\
\text { companies }\end{array}$} & \multicolumn{2}{|c|}{$\begin{array}{c}\text { Employment } \\
\text { numbers }\end{array}$} \\
\hline & $\begin{array}{c}\text { H\&MH- } \\
\text { Tech } \\
\text { compani } \\
\text { es } \\
\end{array}$ & $\begin{array}{c}\text { High- } \\
\text { tech } \\
\text { services }\end{array}$ & $\begin{array}{c}\text { H\&MH- } \\
\text { Tech } \\
\text { companies }\end{array}$ & $\begin{array}{l}\text { High-tech } \\
\text { services }\end{array}$ & $\begin{array}{c}\text { H\&MH } \\
\text { tech } \\
\text { compani } \\
\text { es } \\
\end{array}$ & $\begin{array}{c}\text { High-tech } \\
\text { services }\end{array}$ & $\begin{array}{c}\text { H\&MH } \\
\text { tech } \\
\text { companies }\end{array}$ & $\begin{array}{l}\text { High- } \\
\text { tech } \\
\text { services }\end{array}$ \\
\hline 2002 & 1570 & 877 & 14818 & 14987 & 78 & 60 & 824 & 709 \\
\hline 2003 & 2389 & 962 & 23908 & 18798 & 138 & 82 & 1080 & 1334 \\
\hline 2004 & 2674 & 1009 & 26358 & 20275 & 152 & 80 & 1538 & 1053 \\
\hline 2005 & 2777 & 1347 & 26946 & 21585 & 186 & 124 & 1514 & 1136 \\
\hline 2006 & 2943 & 1707 & 27413 & 24685 & 215 & 177 & 1492 & 1391 \\
\hline 2007 & 3170 & 2335 & 26339 & 21478 & 203 & 251 & 1327 & 1844 \\
\hline 2008 & 2828 & 2438 & 25300 & 28674 & 171 & 239 & 1251 & 1889 \\
\hline 2009 & 2711 & 2601 & 25718 & 31985 & 154 & 276 & 1256 & 2326 \\
\hline 2010 & 2437 & 2632 & 32036 & 25600 & 177 & 344 & 1631 & 2581 \\
\hline 2011 & 2354 & 2599 & 25174 & 31065 & 159 & 336 & 1492 & 2473 \\
\hline
\end{tabular}

Source: own elaboration based on data from Spanish National Statistics Institute (2013), www.ine.es

Knowledge intensive services remained stronger and did not start its downfall till 2011. Even the loss is smaller than in the manufacturing companies. Both started with almost the same number of employees in 2002 (15.000). In 2011, manufacturing companies had 5.000 employees fewer than services. The employment in these companies did not evidence the same contractive trend as it did in 2011 in manufacturing. While in the services sector, the contraction had started the previous year. However, in the case of services, it came back to its previous level in 2011.

Although the number of high-tech companies in Andalusia constituted $10 \%$ of the national number, its employment was only $7 \%$ of the national one.

In Andalusia, the manufacturing companies presents the same tendency as in the national level, as it declined in 2011. However, the number of companies is still double of what it was in 2002 (something that does not occur at national level). The services show the most spectacular rise, as it extend its number over 5 times since 2002 (national level only 3 times). When referring to the number of employees, at the regional level, both started the period with almost the same number of staff (approximately 800). Although the services sector grew 3 times, while the manufacturing did not reach the double number. In 2011, both shows a decline, more intensive in manufacturing. 
There is a difference of 1.000 employees between them in favor of services (1.492 and 2.473).

\section{Research groups}

The importance of Andalusian universities as the creators and developers of knowledge is crucial in the present crisis. However, the research groups suffered a $56 \%$ decrease of funding in the 2010 , comparing to the previous year. In case of University of Jaen the adjustment reached almost $60 \%$. The financing for each Andalusian universities research groups declined, as shown below in Figure 6. The data for 2011, as soon as it is available, could reveal worse perspectives.

Figure 6. Funding granted to R\&D Groups in Andalusia (universities) 2002-2010

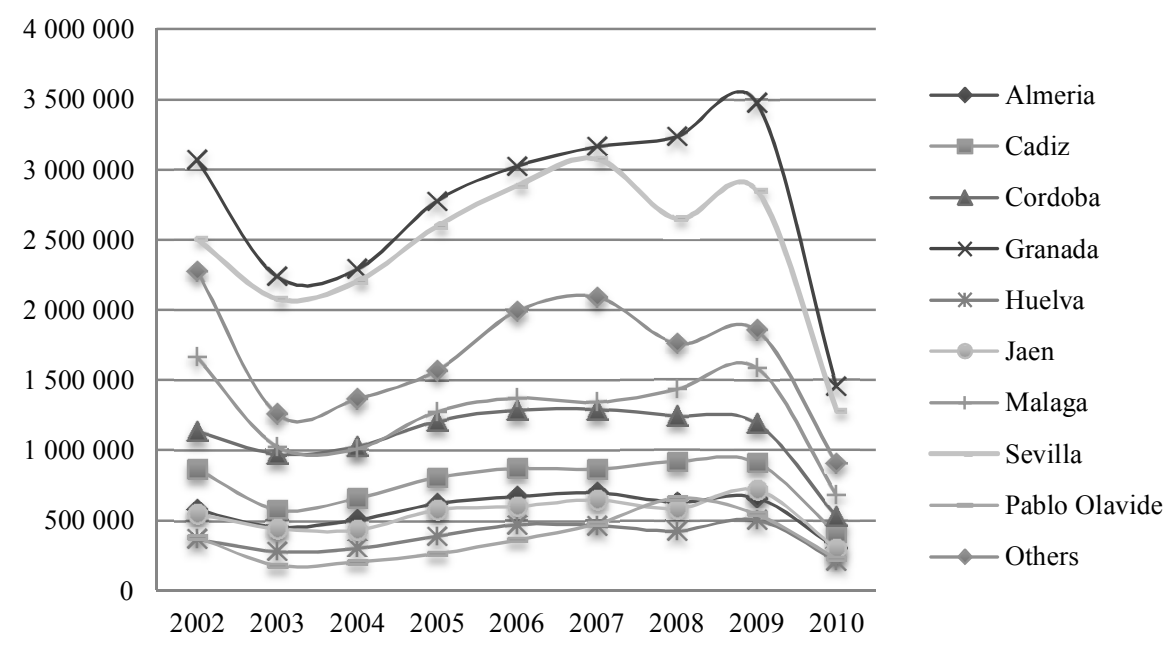

Source: own elaboration based on data from ,Indicadores del Sistema Andaluz de Ciencia y Tecnologia 2010" based on SICA Inventory (2010, p. 33).

${ }^{6} 2001$ and 2011 not available 


\section{Conclusions}

Broadly speaking, the R\&D sector in Spain (at the national level) and in Andalusia (at the regional level) was showing a favorable performance during the period (2001-2010), being very positive results in terms of investment effort, number of companies and jobs created, but the impact of the economic and financial crisis that Spain is suffering has provoked a significant and dramatic change in this positive trend in the two last years.

After 2010, there is an important contraction in quantitative terms in all the categories analyzed (expenditure in research and development, numbers of companies, employment generated and funding granted to universities). This negative trend could be not so important if it was seasonal, but the current and recessive scenario of sharp crisis with continuous decreasing of GDP (over -1\%) that we can observe in Spain and some other European countries do not encourage optimism. Therefore, nowadays we are facing a quite difficult situation with a dramatic impact on the existing businesses (forced to reduce employment in order to survive) and productive activities in this field, even worse for the new ones to start in the near future, the emergence of new production activities of $R \& D$ being prevented or inhibited.

To be honest, we must consider the existence of significant contradictions in the structure and performance of the Andalusia R\&D regional system, the main one is the excessive dependency of the public funds, over $64 \%$ of Andalusia total spending.

We agree with the public intervention on the $R \& D$ sector in order to boost the private investment in this field, and to encourage foreign and private investors to finance these activities. But in the light of the results observed, what seems to be actually happening is rather the substitution of private effort by the public, trying to fill the existing gap, but not fulfilling the expectations.

The contradictions outlined above have become increasingly visible with the crisis, which mainly affects public spending that has suffered important cuts at both levels, national and regional, even more significant in the Andalusia case, being a region of convergence.

In our opinion, it would be crucial in this recessive context to make a solid and consistent intervention by the European Union and its policies to boost the R\&D sectors in peripheral countries, helping the survival of existing companies. On the one hand, it would require the provision of new financial instrument or support lines for essential sectors of the peripheral countries and with their presence compensate for the inevitable reduction in public funds. On the other hand, we suggest a cost/benefits analysis of policies and programs for innovation in Andalusia to verify their effectiveness. 
In any case, it seems clear that a reduction in public spending on $R \& D$ in Spain and Andalusia can generate a negative multiplier effect on the whole system, which would be absolutely devastating. The cuts seem to have a great impact on the universities, as they are the most important agents in the Spanish (and Andalusian) territorial innovation system, so the generation of human capital (essential to enhance innovation) could be negatively affected in the whole territorial system.

The future research lines could enclose an analysis of:

- 2012 data could clear up the trend and the perspectives for the future tendency

- Effects of R\&D spending cut on human resources and brain drain from the Spanish innovation system

- Employment structure by gender in the Spanish and Andalusia science and technology system

\section{References}

Abramovitz M. (1956), Resource and Output Trends in the United States since 1870, National Bureau of Economic Research, Vol. Ocasional Paper 52.

Romero García de Paredes M.J. (2010), Indicadores del Sistema Andaluz de Ciencia y Tecnologia 2010, Consejeria de Economia, Innovación y Ciencia de la Junta de Andalusia, Sevilla.

Denison E. (1962), Source of Economic Growth in the United States and The Alternatives Before Us, Committee for Economic Development.

Escuela de Organización Industria - EOI (2010), Evaluación del sistema andaluz de innovación 2010, Fundación EOI, Madrid.

EUROSTAT, Science and Technology (2011), Total intramural R\&D expenditure (GERD) by sectors of performance, www.eurostat.eu (10.02.2013).

Freeman C., Clarke J., Soete, L. (1982), Unemployment and technical innovation: a Study of Long Waves in economic Development, Frances Pinter, Londres.

Freeman C., Soete L. (1997), The Economics of Industrial Innovation, The MIT Press, Massachusetts.

González Romero G. (2010), Metodología e Indicadores para el Análisis Territorial de la Innovación. Su Aplicación a Andalucia, "Clm Economía", No. 16.

Hollanders H. et all (2012), Regional Innovation Scoreboard 2012, DG Enterprise and Industry 2012, European Commission, Belgium, doi:10.2769/55659.

Institute of Statistics and Cartography of Andalusia, Estadistica sobre actividades de I+D. Resultados para Andalusia (data for 2010 and 2011, state for 10 march 2013).

Lucas R.E. (1988), On the mechanics of economic development, "Journal of Monetary Economics", Vol. 22, http://dx.doi.org/10.1016/0304-3932(88)901687 .

National Stadistics Institute of Spain, http://www.ine.es (7.02.2013). 
OCDE y Eurostat, (2005), Manual de Oslo, Guía para la recogida e interpretación de datos sobre la innovación, Grupo Tragsa, Madrid.

OCDE, (1998), The OCDE jobs strategy: technology, productivity and job creation. OCDE, Paris.

Romer P. (1986), Increasing returns and long-run growth, "Journal of Political Economy", Vol. 94, http://dx.doi.org/10.1086/261420.

Romer P.M. (1990), Endogenous Technological Change, "Journal of Political Economy", Vol. 98, http://dx.doi.org/10.1086/261725.

Salter W. (1960), Productivity and technical change, Cambridge University Press, London.

Schumpeter J.A. (1939), Business Cycles: A Theoretical, Historical and Statistical Analysis of the Capitalist Process, McGraw- Hill, New York.

Schumpeter J.A. (1968), Capitalismo, Sociedad y Democracia, Aguilar, S.A. De Ediciones, Madrid.

Schumpeter J.A. (1967), Teoría del desenvolvimiento económico, Fondo de Cultura Económica, México D.F.

Solow R. (1957), Technical Change and aggregate production function, "The Review of Economics and Statistics", Vol. 39, http://dx.doi.org/10.230 7/1926047.

Solow R. (1956), A Contribution to the Theory of Economic Growth, "Quarterly Journal of Economics", Vol. 70, http://dx.doi.org/10.2307/1884513. 